\title{
CURRENCY AND YIELD CO-INTEGRATION BETWEEN A DEVELOPED AND AN EMERGING COUNTRY: THE CASE OF TURKEY*
}

\author{
AHMET CAN INCI ${ }^{*}$
}

Sabancı University

\begin{abstract}
The relationship between currencies and the interest rates of different maturities is examined in the Turkish-US context. The real exchange rate between the new Turkish lira (YTL) and the US dollar is found to depend on both short- and long-term real US-Turkish interest rate differences. Cointegrating regressions generate negative and significant coefficients for long-rate differential, consistent with uncovered interest parity and the expectations hypothesis. On the other hand, positive coefficients for real short-term rate differential reveal the forward premium puzzle and the failure of uncovered interest parity for short-horizons. Results are partly driven by the very different risk characteristics of short-term US bonds and the Turkish currency.
\end{abstract}

JEL Classification: F31, E43, G14

Key words: exchange rates, interest rates, uncovered interest parity, forward premium puzzle.

\section{GELIŞMIŞ VE GELIŞMEKTE OLAN ÜLKELER ARASINDA KUR-GETIRI EŞBÜTÜNLEŞMESI: TÜRKIYYE ÖRNE $\breve{I}$}

$\ddot{O Z E T}$

Döviz kurları ve değişik vadeli faiz oranları arasındaki ilişki Türkiye-ABD ekonomileri içeriğinde incelenmiştir. Yeni Türk Lirası (YTL) ve Amerikan Doları arasındaki reel kur oranı, hem kısa vadeli Amerikan-Türk reel faiz oranı farkına, hem de uzun vadeli Amerikan-Türk reel faiz oranı farkına bağlı olduğu bulunmuştur. Eşbütünleşme gerilemeleri uzun vadeli faiz farkı için negatif ve belirgin katsayılar elde etmiştir. Bu sonuç Garantisiz Faiz Oranı Hipotezi ve Beklentiler Hipotezi ile uyumludur. Öte yandan, reel kısa vadeli faiz oranı farkı için bulunan pozitif katsayılar, vadeli prim bilmecesini ortaya çıkarmaktadır. Bu sonuç da kısa vadeler için Garantisiz Faiz Oranı Hipotezinin geçersizliğini göstermektedir. Elde edilen bulgular kısmen kısa vadeli Amerikan tahvillerinin ve Türk Lirasının çok farkl risk özelliklerinden kaynaklanmaktadır.

\section{JEL Sinıflaması: F31, E43, G14}

Anahtar kelimeler: döviz kurları, faiz oranları, garantisiz faiz oranı hipotezi, vadeli prim bilmecesi.

* I would like to thank Josh Coval, Meltem Denizel, David Humphrey, Gautam Kaul, Nejat Seyhun, and the two anonymous referees for their suggestions, and seminar participants at Florida State University and Sabanc1 University for their comments.

** Ahmet Can İnci is an Assistant Professor in the Faculty of Management at Sabancı University, Orhanlı - Tuzla, 34956, Istanbul, Turkey. E-mail: acinci@ sabanciuniv.edu

Boğaziçi Journal Vol. 21, no. 1-2 (2007), pp. 1-20. 
Monetary authorities use interest rates to achieve numerous economic policy goals. For example, the central bank may want to stimulate or slow down an economy, attract foreign capital, reduce the trade deficit, or influence the domestic currency dynamics by utilizing interest rates. In addressing the relationship between interest rates and currency dynamics, rational expectations theory says that high interest rates are to compensate for future currency depreciation. However, empirical studies demonstrate the complete opposite: high interest rate currencies appreciate and become more valuable. The anomaly is called the forward premium puzzle (FPP), documented first by Frankel (1979) and named by Fama (1984). Studies in the literature, such as Bekaert et al. (2002), Brandt and Santa-Clara (2002), and Collin-Dufresne et al. (2004), have generally examined the puzzle and the currency-interest rate dynamics among developed countries. Bekaert et al. (2002) find evidence for the puzzle when short-rates are used, while the puzzle diminishes when long horizon rates are used. The latter two studies employ sophisticated stochastic diffusion models for their statistical analyses using developed country data. However, the globalization of financial markets over the last two decades and the attractive profit prospects in emerging economies warrant an examination of the dynamics between developed and developing countries. ${ }^{(1)}$ In this paper, a theoretical framework is proposed to expose and to account for the puzzle between an emerging country, Turkey, and a developed country, the US. Empirical investigation based on the model will show that the FPP appears in the short-term rate and exchange rate relationship. On the other hand, the expectations theory will hold in the relationship between long-term rates and the exchange rate.

Previous studies in the literature, such as Bali (2000), generally explore short-term rates since they can be changed more directly by the monetary authority. However, the longer maturity bond yield reaction to these changes should also be taken into account. Since the term structure of interest rates conforms to humped, upward sloping, or downward sloping patterns, there is not a positive, linear response in long-term yields as short-term rates change. Accordingly, this article examines both the short- and the long-term in establishing the relationship between the $\$ / Y T L$ dynamics and interest rates.

Both the Turkish economy and the US economy exhibit different trends and characteristics during the period of investigation from March 1996 through August 2006. The Turkish nominal rates are very high during the late 1990s. The 1-year rate is above $100 \%$ and averages around $120 \%$, while the short-term rate is below $100 \%$, averaging roughly $80 \%$. This period also corresponds to chronically high inflation with Us (2004) demonstrating the impact of depreciation of the Turkish currency on high inflation rates with vector auto-regression analyses. 2000 and 2001 are marked by financial and economic crises, which are especially severe from February through October 2001. ${ }^{(2)}$ During this time, the term structure in Turkey is inverted with higher short-term rates compared to long term-rates. Since the crisis, the interest rates are in decline reaching roughly $20 \%$ by August 2006. During this recent period, the long-term rates are higher than the corresponding short-term rates.

Before 1980, Turkey followed a fixed exchange rate system with controls on foreign currency transactions. Throughout the 1980s, Turkey moved towards an export-influenced growth strategy along with the liberalization of the markets. Foreign investors were allowed to invest in domestic markets and to repatriate their proceeds starting from August 1989. Convertibility of the Turkish lira was put into effect in the beginning of 1990. Also following August 1989, the Central Bank of the Republic of Turkey (CBT) introduced the interbank spot exchange market to determine the official exchange rate. This system led to real appreciation of the Turkish currency and increased the foreign deficit, which eventually led to the April 1994 financial crisis. There were two unsuccessful 
IMF-backed stabilization programs between 1994 and December 1999. Turkey adopted a crawling peg regime in December 1999 (Tastan, 2005). As examined in Ertuğrul and Selçuk (2001) and Erlat (2003), following the financial turmoil in December 2000 and another crisis in February 2001, the Turkish lira was eventually left to float.

The exchange rate between the YTL and the US dollar during the 1996-2006 period shows a depreciating Turkish currency in general, but there are very different patterns. Up until the crises of 2001, the depreciation displays a stable pattern. During the crises, the YTL/ $\$$ rate jumps from 0.67 to 1.60 from February through October 2001, which is almost a $140 \%$ depreciation. As a matter of fact, in just a few days from February 23 to February 26, the Turkish lira depreciates by 56\%. Since the crises, the Turkish lira exhibits a stabile pattern. The old Turkish lira is replaced by the new YTL during this stable period by practically crossing out six zeros from the old currency.

The financial crises from late 2000 through 2001 can be considered a repercussion of the Asian and Russian economics crises. On the other hand, the stable depreciation of the Turkish lira adopted as the official exchange rate policy by the Central Bank of Turkey (CBT) throughout the 1990s may not have been favored by all national and international institutional investors. The coordinated efforts of these investors may have been another factor in the depreciation of the Turkish currency.

The Turkish macro-economy and its related indicators exhibited significantly higher risks and different characteristics compared to those of the US economy. Berüment and Dinçer (2004) focus on the effect of the exchange rate risk on the Turkish economy and use the ratio of the total foreign exchange liabilities to (1) the total reserves, (2) the reserves of the CBT and (3) the Turkish lira liabilities as the three measures for the exchange rate risk obtained from the CBT, since these variables directly measure the strength of the CBT in stabilizing the real exchange rate. The empirical evidence provided by Berüment and Dinçer (2004) is such that the higher exchange rate risk is associated with a depreciation of the local currency, an increase in prices, and a decrease in output.

Selçuk (2005) examines the post-2001 floating exchange rate period and finds that the CBT was effective in containing volatility and reducing the average inflation rate. The CBT followed the developments in the exchange rate market when making interest rate cutting decisions. However, it was proactive on the volatility through selling auctions. These findings provide support for the CBT claim that it was only concerned about exchange rate volatility, not the level or direction of exchange rates. It is also shown by Selçuk (2005) that the degree of exchange rate pass-through is low in Turkey, and that has helped the monetary authority to switch into an explicit inflation targeting policy. The negative effect of the substantial appreciation of the Turkish lira on external competitiveness during the float was offset to a large extent by an increase in productivity and a fall in real wages. Akinci et al. (2006) and Berüment (2007) also provide evidence for the effectiveness of foreign exchange purchase interventions for the Turkish economy conducted by the CBT in the post-crisis period, especially after $2003 .{ }^{(3)}$

Finally, when the US interest rates are examined, patterns of stability and low values are seen, typical of developed country rates. The average rates of $5.5 \%$ in the late $1990 \mathrm{~s}$ drop all the way down to $1.5 \%$ in the beginning of 2004 and increase back to the 5\% level by late 1996. Long term-rates are higher than short-term rates with the only exception of the inverted term structure from October 2000 to April 2001. As these characteristics demonstrate, the analyses in this study correspond to a period of different interest rate and exchange rate patterns. 
The theoretical framework in this study starts with a portfolio that consists of short- and long-term US government bonds and Turkish lira (YTL) (representing the short-term Turkish investment). Many fixed income portfolio decisions are driven by asset allocation, investment horizon, or immunization. Here the goal is to maintain a desired risk level as individual assets become less or more attractive. This is achieved by studying the supply-demand dynamics of the assets in the portfolio. The long-term bond is more risky than the short-term bond but less risky than the foreign bond and can be a substitute to both assets. In this setting, when the short-term rate increases in the US relative to Turkey, the shortterm bond price declines because yields and prices move in opposite directions. The demand for these US T-bills increases while the demand for the alternative long-term bonds declines. The decline in demand for long-term bonds increases the demand for the other alternative, the Turkish lira (YTL), and this is reflected to an instant increase in the value of the Turkish lira (i.e., an instant depreciation of the US dollar). Furthermore, high priced long-term bonds with lower yields will be negatively associated with the instant Turkish lira appreciation. In steady state equilibrium, the demand functions of US bonds will adjust to the shock and lead to an appreciation of the US dollar, which is the FPP. Similarly, the supply-demand dynamics will work in the reverse direction if short rates are reduced.

The empirical analyses document the following relationships in real terms:

- The contemporaneous US dollar-Turkish lira exchange rate and the short-term US-Turkish interest rate differential are positively correlated;

- The change in the \$/YTL exchange rate and the short-term US -Turkish interest rate differential are negatively correlated;

- The contemporaneous $\$ / Y T L$ exchange rate and the long-term rate differential are negatively correlated;

- The change in the exchange rate and long-term rate differential are positively correlated.

\section{REVIEW OF LITERATURE}

The often tested theory in the literature is the Expectations Hypothesis (EH) or Uncovered Interest Parity (UIP). EH says that forward/futures rates are unbiased estimates of expected future spot rates. In other words, the futures-spot basis, or the interest rate difference from covered interest parity, can predict changes in future exchange rates. Empirically, if the change in the exchange rate is regressed on the domestic and foreign interest rate difference, the regression slope coefficient is expected to be equal to one according to EH (which says forward rates are expected future spot rates). However, numerous studies have consistently found the coefficient to be significantly negative. The studies range from Frankel (1979), Flood and Rose (2001), Bekaert and Hodrick (2001), to Wu (2007) and have used different currencies, time periods, sample sizes, and estimation methods, reaching the same conclusion. This is the forward premium puzzle (FPP) named by Fama (1984).

Studies since then have examined the issue using different forecast horizons and empirical models. Chinn and Meredith (2002), Meredith and Chinn (1998), and Alexius (1993) report evidence in line with the uncovered interest rate parity with positive slope coefficients for long-term interest rates over long horizons. On the other hand, Dornbusch (1976), Baxter (1994), and Kempa et al. (1999) have proposed that prices are sticky and move slowly over time in reaction to economic shocks and innovations. Term structure modeling studies using stochastic diffusion processes have focused on single countries and tried to explain the interest rates of all maturities. Dai and Singleton $(2002,2003)$ 
and Duarte (2004) have developed affine models where the interest rates are linear functions of the underlying macroeconomic factors. The statistical characteristics of these factors are identified in these studies; however, the factors themselves are left undefined. Ang and Piazzesi (2002) and Iwata and $\mathrm{Wu}(2005)$ try to identify these macroeconomic factors that impact interest rates. Ahn et al. (2002) develop quadratic term structure models with better empirical performance. Although these studies have introduced sophisticated theoretical models, the major drawback is that they are not concerned with the intuitive or practical explanations of how the theoretical model works.

Another strand of research has focused on the statistical distributions of currency returns. Zhou (2002) has modeled the volatility of returns using GARCH models, while Sarno and Valente (2005) have developed risk management strategies using density forecasts of exchange rates. Finally, many currency and interest rate data are nonstationary and have unit roots. Cointegrating regression models have been developed to filter the nonstationarity and to extract the actual relationship between currencies and interest rates. These studies have produced mixed results. For example, Meese and Rogoff (1988) find no evidence of a significant relationship between real exchange rates and long-term real interest rate differentials, but they do not examine long- and short-rates simultaneously. Barkaulas et al. (2003) test the forward premiums of currencies and find that the risk premium is time-varying but stationary. The majority of the studies examine the relationship among developed countries. This article provides a detailed analysis of the dynamics between an emerging country, Turkey, and a developed country, the US, with the sticky price approach and cointegrating regressions. ${ }^{(4)}$

The common conclusion in the literature is that the relationship between currency returns and interest rate differentials depends on the term structure of the interest rates and the financial risks embedded in the country as perceived by investors. This paper addresses these points with a simple term structure of short- and long-term rates and with its impact on the $\$ /$ YTL dynamics.

The empirical analyses start by justifying the theoretical risk ranking of the US short- and long-term bonds, and the Turkish currency. Cointegrating regressions of contemporaneous $\$ / Y T L$ rate generate negative and significant coefficients for long-term interest rate differentials. This is consistent with UIP, and therefore, the EH is valid for long horizons. On the other hand, positive coefficients obtained for the real short-term interest rate differentials demonstrate the FPP, and the failure of the UIP. The results are robust to regressions where the dependent variable is the future \$/YTL depreciation.

In the next section, the general theory is presented. The following sections explain the empirical tests and describe the data and the descriptive statistics. The final section presents the results, followed by the conclusion.

\section{GENERAL THEORY}

The failure of the UIP can be accounted for in a more realistic risk-averse world where the term structure of interest rates is relevant. The investor is assumed to have three assets: short-term US bonds, long-term US bonds, and short-term Turkish government bonds (where the change in the \$/YTL exchange rate is the main source of risk). The investor forms a portfolio based on his/her risk tolerance and changes the proportions of the three assets as they become more attractive or less attractive, while maintaining the desired risk level. The portfolio update depends on whether these assets are alternatives or complements of each other. Any two assets having similar risk characteristics 
are termed substitutes and have demand functions that move in opposite directions. On the other hand, two assets with different risk characteristics, i.e., a very risky asset and an almost riskless one, are complements and have demand and price functions moving in the same direction.

In the portfolio of three securities, each asset pair has a direct substitution effect and an indirect complementary effect due to the third asset (see Driskill and McCafferty, 1987, for details). Whether assets end up as net substitutes or complements depends on the underlying parameters describing their risk characteristics. The short-term US bond has minimal risk for practical purposes. The risk associated with the short-term Turkish bond can be proxied by the volatility of the \$/YTL return conditional on time. Finally, the risk proxy for the US long-term bond is the conditional volatility of long-term rates. The conditional risks of the latter two assets relative to each other lead to the four cases summarized in Figure 1.

Figure 1

Substitute and Complement Assets based on Relative Risk

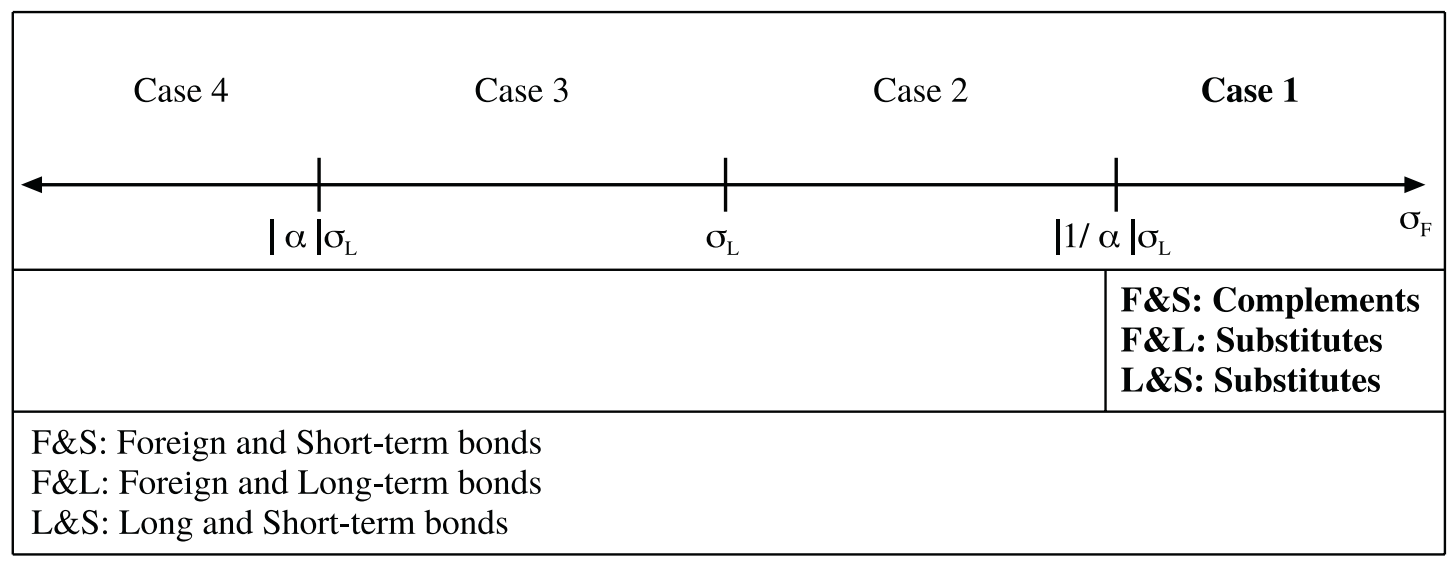

The assets are short-term US bond (S) with no risk, long-term US bond (L), and Turkish currency/bond (F). $\sigma_{L}$ is the standard deviation of long-term US returns; $\sigma_{F}$ is the standard deviation of change in the $\$ / Y T L$. The correlation coefficient between US long-term bond and YTL is $\alpha$. In Case 1, $\sigma_{\mathrm{F}}$ is much higher than $\sigma_{\mathrm{L}}$. YTL and long-term US bonds (F\&L) are substitutes; so are long-term and short-term US bonds (L\&S). YTL and short-term US bonds (F\&S) have very different risk characteristics and act as complements. Case 2 and Case 3 correspond to $\sigma_{\mathrm{F}} \approx \sigma_{\mathrm{L}}$ and Case 4 corresponds to $\sigma_{\mathrm{F}}<<\sigma_{\mathrm{L}}$.

The empirical study here is based on the more realistic and plausible Case 1, where the volatility of the \$/YTL return is higher than the volatility of the US long-term-interest rates. The fact that the exchange rate return has higher volatility is empirically justified in Backus et al. (2001) and Engle and West (2004). Moreover, as explained in the data and preliminary analysis section and shown in Panel C of Table 1, \$/YTL volatility is much higher than that of the US long-term interest rate. The US long-term rate volatility in turn is higher than the US short-term volatility, validating Case 1. The US long-term bond is more risky than the US short-term bond but less risky than the Turkish currency and ends up as a substitute for both. And the YTL and US short-term bonds are complements of each other. ${ }^{(5)}$ The empirical verification is provided in the section on data and preliminary analysis.

In this theoretical setting, suppose that the US short-term interest rate rises. The price of the bond is lower (since yields and prices move in opposite directions), and the investor wants to increase the proportion of this higher return asset while keeping the risk level the same. This has two opposite effects on the demand for the YTL in the portfolio. The first, negligible effect is due to the very weak substitution between the US short-term bond and the YTL. The second is the dominant complementary 
effect which increases the demand for the YTL. ${ }^{(6)}$ This will immediately increase the value of the YTL (US dollar will depreciate immediately). Empirical investigation of this conjecture should lead to a positive relationship between short-term interest rate differentials and the contemporaneous exchange rate. ${ }^{(7)}$

The relationship between long-term interest rate differentials and the \$/YTL is more direct. Both are strong substitutes for each other. Therefore, as the demand for the US long-term bond decreases, the demand for the YTL increases, leading to an immediate increase in the value of the YTL. The empirical consequence is a negative relationship between long-term interest rate differentials and the contemporaneous exchange rate.

\section{EMPIRICAL MODEL}

Let $S(t)$ denote the spot price (exchange rate) of YTL in US dollars, and $F(t, T)$ denote the futures/ forward price (in dollars) at time $t$. Under the risk-neutral measure, $N$, the futures price is an unbiased estimate of the future spot exchange rate. ${ }^{(8)}$

$$
F(t, T)=E_{t}^{N} F(T, T)=E_{t}^{N} S(T) .
$$

Subtracting $S(t)$ from both sides of (1) and then dividing the equation by $S(t)$ gives the futures-spot basis as just the expected spot currency return,

$$
\frac{F(t, T)-S(t)}{S(t)}=E_{t}^{N} \frac{S(T)-S(t)}{S(t)} .
$$

The general version of the uncovered interest rate parity imposes a constant currency risk premium. This leads to the following regression,

$$
\frac{S(T)-S(t)}{S(t)}=\alpha+\beta \frac{F(t, T)-S(t)}{S(t)},
$$

under the null hypothesis of $\beta=1$. The tests on the UIP in the literature often use log returns rather than percentage returns, and the basis is often replaced by the US-Turkish yield difference from the covered interest parity of no arbitrage:

$$
s(t+\tau)-s(t)=\beta_{0}+\beta_{1}\left(Y_{U S}(t, \tau)-Y_{T U R}(t, \tau)+\varepsilon_{t} .\right.
$$

This is qualitatively the same as (3), and where $s(t+\tau)-s(t)$ is the log return of the \$/YTL and $Y_{U S}(t, \tau)-Y_{T R}(t, \tau)$ is the differential of the US and Turkish interest rates.

One shortcoming of this approach is that the forecast horizon is generally picked as 1-month. To account for quick reactions to changes in interest rates in today's professional investment markets, a contemporaneous relationship between exchange rates and interest rates can be developed. It is based on the sticky price exchange rate model of Baxter (1994) coupled with cointegrating regressions.

The log of the real exchange rate is defined as $q(t)=s(t)-p_{U S}(t)+p_{T U R}(t)$, where, $s(t)$ is the log of the nominal exchange rate, $p_{U S}(t)$ is the log of the US consumer price index, and $p_{T U R}(t)$ is the log of 
the Turkish consumer price index. The sticky price of the real exchange rate, $q(t)$, is assumed to adjust slowly to disturbances and come back to its long-run equilibrium value, $\bar{q}(t)$, at a constant rate, $\theta$, known as the coefficient of adjustment:

$$
E_{t}(q(t+\tau)-\bar{q}(t+\tau))=\theta^{\tau}(q(t)-\bar{q}(t)), 0<\theta<1
$$

Using $E_{t}(\bar{q}(t+\tau)=\bar{q}(t)$ and rearranging (5), we get

$$
\theta^{\tau} q(t)=E_{t}(q(t+\tau))-\bar{q}(t)+\theta^{\tau} \bar{q}(t) .
$$

Finally, subtracting $q(t)$ from both sides and dividing both sides by $\theta^{\tau}-1$, one can find

$$
q(t)=\rho\left(E_{t}(q(t+\tau))-q(t)\right)+\bar{q}(t)
$$

where $\rho=1 /\left(\theta^{\tau}-1\right)<0$. Replacing the real expected currency change in (7) with the real domestic and foreign interest rate difference gives,

$$
q(t)=\rho\left(y_{d}(t, \tau)-y_{f}(t, \tau)\right)+\bar{q}(t) .
$$

Equation (8) shows a direct relationship between the contemporaneous real \$/YTL and the real US - Turkish interest rate differential for empirical analysis. If the EH holds, an increase in the US real interest rate relative to the Turkish interest rate immediately decreases the real exchange rate. But if the theoretical conjecture of the section on "General Theory" is valid, we should see the opposite for short rates: as the US short rate increases relative to the Turkish short rate, the current \$/YTL increases. On the other hand, there should be a negative contemporaneous relationship between longterm interest differentials and the $\$ / Y_{T L}{ }^{(9)}$

Edison and Pauls (1993) have suggested that the relationship between exchange rates and interest rates can be established better with additional variables. However, unless there is a sound theoretical basis, the arbitrary inclusion of explanatory variables might contaminate the tests with specification problems. Here, the additional explanatory variable is the long-term interest rate differential consistent with the theoretical layout. Therefore, cointegration regressions are performed on the following model:

$$
q(t)=\rho_{0}+\rho_{l}\left(y_{s, U S}(t)-y_{S, T U R}(t)\right)+\rho_{2}\left(y_{l, U S}(t)-y_{l, T U R}(t)\right)+\rho_{3} t+\varepsilon_{i}
$$

The sign of $\rho_{2}$ is expected to be negative. The sign of $\rho_{1}$ will be positive if short rates and YTL are complements. This will be consistent with the FPP. If $\rho_{1}$ ends up as negative, then UIP will hold for short- as well as long-term rates.

\section{DATA AND PRELIMINARY ANALYSIS}

The Eurocurrency market is an enormous and very liquid interbank market. A single location ensures comparability across different currency denominations. The use of Eurocurrency rates minimizes 
possible frictions caused by differences in capital controls, and other government regulations. Therefore, end of month Eurocurrency deposit rates from Global Insight are used for the interest rate data. For short-term rates, 1-month Eurocurrency yields are used. For long-term interest rates, 1-year Eurocurrency yields are used. Longer maturity yields for Turkey were not available for an equal or longer sample period. Price changes are measured by the seasonally unadjusted consumer price index data. The monthly exchange rate is defined as the new Turkish lira -YTL- in terms of US dollars and is also from Global Insight. The sample extends from March 1996 through August 2006 mainly because that is as far back as the 1-year Turkish Eurocurrency yields go. The ex-ante real short-term interest rate and the real long-term interest rate are constructed by computing a measure of expected inflation under the assumption that it follows an autoregressive process. ${ }^{(10)}$

The first goal is to determine whether the data are empirically consistent with the theoretical discussion. Is the risk of the short-term US bond (represented by the standard deviation of the US 1-month yield) less than that of the long-term US bond? Is the risk associated with the US long-term bond less than the risk associated with the Turkish bond (measured by the standard deviation of the change in the $\$$ / YTL)? Affirmative answers to both questions will correspond to Case 1 of Figure 1 described above.

Table 1

Country Risk Rankings

\section{Panel A. Country Risk Rankings - March 1990 through September 2006}

Institutional Investor Country Credit Survey

$\begin{array}{ccc} & \frac{\text { US }}{4.65} & \text { TUR } \\ \text { Mean } & 40.06 \\ \text { St. Error } & 1.74 & 14.03\end{array}$

$\underline{\text { Euromoney Country Risk Rankings }}$

$\begin{array}{ccc} & \underline{\text { US }} & \text { TUR } \\ \text { Mean } & 4.11 & 61.09 \\ \text { St. Error } & 2.37 & 13.08\end{array}$

Panel B. Country Risk Rankings - March 1996 through September 2006

$\underline{\text { Institutional Investor Country Credit Survey }}$

$\begin{array}{lcc} & \frac{\text { US }}{4.82} & \frac{\text { TUR }}{68.82} \\ \text { Mean } & 4.82 & 8.39 \\ \text { St. Error } & 2.04 & \end{array}$

Euromoney Country Risk Rankings

$\begin{array}{ccc} & \underline{\text { US }} & \text { TUR } \\ \text { Mean } & 3.50 & 68.95 \\ \text { St. Error } & 1.16 & 7.47\end{array}$

Panel C. Coefficient of Variation (CV) and St.Dev. of US returns vs. YTL Returns

\begin{tabular}{|c|c|c|c|}
\hline & \multicolumn{2}{|c|}{ US } & \multirow[t]{2}{*}{ TUR } \\
\hline & Rs & RI & \\
\hline St. Deviation & 0.0026 & 0.0036 & 0.0842 \\
\hline $\mathrm{CV}$ & 1.86 & 2.12 & 19.14 \\
\hline
\end{tabular}

Panel A and Panel B present mean and standard deviation of Institutional Investor and Euromoney country risk rankings. The rankings have been compiled and computed from semi-annual issues of Euromoney and Institutional Investor. The lower the mean value of the rank, the lower the country risk. In Panel C Rs is the US short-rate and Rl is the US long-rate. 
There are two publications that provide semiannual rankings of countries based on their risk profiles. Institutional Investor and Euromoney develop country risk ratings by calculating the weighted average of the chance of default, political risk, economic performance, debt indicators, credit ratings, and access to banks, short-term finance, and capital markets. The last set of rankings used in this article can be found at Euromoney (2006) and Institutional Investor (2006). Time series of country risk rankings are created for both the US and Turkey using these independent Euromoney rankings and Institutional Investor rankings. Moments of the rankings are presented in Table 1 both for the more extended period starting from March 1990 (Panel A), and for the sample period of this study starting from March 1996 (Panel B). The results clearly prove the US as the less risky country at conventional statistical significance levels. Moreover, a long-term US bond can comfortably be conjectured to have less risk than a Turkish bond of any maturity or the \$/YTL dynamics. However a more formal empirical justification of the risk rankings is necessary and this is achieved with the descriptive statistics on the data. The last panel of the table presents the standard deviation and coefficient of variation (CV) values as alternative measures of risk for the US short rate, the US long rate, and the YTL. The YTL exhibits much higher risk than those of the US rates for either measure. The CV of the YTL is at least 9 times more than the long-term CV of 2.12, while the CV of the short rate is 1.86. Additionally, consistent with theory, the US long-term rate exhibits more risk than the US short rate.

Table 2 is about the variables used in the regressions. Mean and standard deviation values of real shortand long-term interest rates are given in Panel A. The Turkish interest rates have higher unconditional volatilities compared to their US counterparts. Panel B presents the means and standard deviations of interest rate differentials between the US and Turkey. Sample moments of short-term interest rate differentials are followed by those of long-term interest rate differentials. Panel C presents the sample moments for real \$/YTL in levels and returns.

Table 2

Properties of Interest Rates and Currencies

\begin{tabular}{|c|c|c|c|c|}
\hline \multicolumn{5}{|c|}{ Panel A. Summary Statistics: Interest Rates } \\
\hline & \multicolumn{2}{|c|}{ Short-term } & \multicolumn{2}{|c|}{ Long-term } \\
\hline & Mean & Std Deviation & Mean & Std Deviation \\
\hline US & $\overline{0.0014}$ & 0.0026 & $\overline{0.0017}$ & 0.0036 \\
\hline Turkey & 0.0092 & 0.0223 & 0.0093 & 0.0476 \\
\hline \multicolumn{5}{|c|}{ Panel B. Summary Statistics: Interest ratedifferentials } \\
\hline & \multicolumn{2}{|c|}{$\mathrm{y}_{\mathrm{s}, \mathrm{US}}-\mathrm{y}_{\mathrm{s}, \mathrm{TUR}}$} & \multicolumn{2}{|c|}{$\mathrm{y}_{1, \mathrm{US}}-\mathrm{y}_{1, \mathrm{TUR}}$} \\
\hline US - Turkey & Mean & Std Deviation & $\overline{\text { Mean }}$ & Std Deviation \\
\hline \multicolumn{5}{|c|}{ Panel C. Summary Statistics: Currency prices } \\
\hline & \multicolumn{2}{|c|}{$\mathrm{Q}_{\mathrm{t}}$} & \multicolumn{2}{|c|}{ Depreciation rate, $\mathrm{Q}_{\mathrm{t}+1} / \mathrm{Q}_{\mathrm{t}}-1$} \\
\hline & Mean & $\underline{\text { Std Deviation }}$ & Mean & Std Deviation \\
\hline $\begin{array}{c}\text { Turkish Lira } \\
\text { YTL }\end{array}$ & 0.6614 & 0.3095 & 0.0044 & 0.0842 \\
\hline
\end{tabular}

Panel A presents means and standard deviations of the US and Turkish yields. Panel B presents mean and standard deviation of the real short-term and long term differentials between the US and Turkish yields. Panel C is the means and standard deviations of real new Turkish lira $\left(\mathrm{Q}_{\mathrm{t}}\right)$, and changes in the real new Turkish lira. 
The cross-sectional results show that the \$/YTL data have much higher volatility than the interest rate differentials. Standard deviation of the $\$ / Y T L$ is higher than those of the short and long-term interest rate differentials by as much as six times. These statistics also demonstrate the difficulty researchers have in trying to forecast exchange rate returns as explained in Engel and West (2004). Finally, longterm differentials have twice the standard deviation of short-term differentials.

The results support Case 1 of Figure 1 and are consistent with previous studies such as those of Backus et al. (2001) and Baxter (1994). The Turkish currency/bond has much higher risk than the US shortterm bond, making it a substitute for the US long-term bond only. The US long-term bond, on the other hand, can also be a rough substitute for the US short-term bond since it is less risky than the YTL. YTL acts therefore as a substitute of a substitute for the US short-term bond. They are at opposite ends of the risk spectrum and are complements of one another. ${ }^{(11)}$

Next, the immediate and steady state reactions of the $\$ / Y T L$ to short rate changes are examined. The goal is to answer whether there is indeed a positive contemporaneous relationship between the YTL and the short rate difference demonstrating the FPP.

\section{EMPIRICAL RESULTS}

\section{Unit Root Tests}

Previous studies report that real currencies and interest differentials may be non-stationary and have unit roots (Meese and Rogoff, 1988). Such data are known to have long memory, where a shock will have a persistent long term impact. Cointegrating regressions should be conducted in such cases.

Unit root tests notoriously have low power. Therefore, five different tests are conducted to determine whether the data indeed contain unit roots. Three of them are independent versions of augmented Dickey-Fuller tests: ADF based on the OLS t-statistic, ADF2 based on the rho test from the OLS autoregressive coefficient estimates, and ADF3 based on the OLS F statistics. Serial correlations in the tests are controlled by including higher order autoregressive terms. The critical values and the details of these tests are provided in Dickey and Fuller (1981), Said and Dickey (1984), and Fuller (1996). The last two tests are the Phillips-Perron Zrho unit root test and the Phillips-Perron Zt unit root test following Perron (1988). The test results are reported in Table 3, Panel A. Evidence against nonstationarity is strongest for the \$/YTL. Overall, neither the Dickey-Fuller nor the Phillips-Perron tests rejects the null hypothesis of difference stationarity for any of the data at conventional significance levels. The only exception is the Phillips-Perron Zrho test of the short-term real interest rate differential. Since each time series is nonstationary at least by one test and since real long- and short-term interest differentials possess at least a near unit root, the relationship between the real \$/YTL and real longand short-term interest differentials should be determined using cointegrating regressions.

If the short and long term yield differentials are cointegrated with one another, then there is more than one cointegrating relationship between the real \$/YTL, real short, and real long rate differentials. Therefore, the explanatory variables should be investigated to see if they are cointegrated with each other (Phillips and Hansen, 1990). Panel B reports the results of augmented Dickey-Fuller, Phillips' Zrho and Zt cointegration tests between real long- and real short-term interest rate differentials. The results fail to reject the null of no cointegration at $5 \%$ significance. 
Table 3

Unit Root and Co-integration Tests

\begin{tabular}{cccc}
\hline Panel A. Unit Root Tests & $\mathrm{q}_{\mathrm{t}}$ & $\mathrm{y}_{\mathrm{s}, \mathrm{US}}-\mathrm{y}_{\mathrm{s}, \mathrm{TUR}}$ & \\
\cline { 2 - 3 } ADF & -1.1460 & -1.8405 & $\frac{\mathrm{y}_{1, \mathrm{US}}-\mathrm{y}_{1, \mathrm{TUR}}}{2}$ \\
ADF2 & -2.7286 & -18.9203 & -2.7270 \\
ADF3 & 0.0015275 & 0.0158946 & -13.8004 \\
Phillips-Perron Zrho & -2.9603 & -20.3666 & -7.6395 \\
Phillips-Perron Zt & -1.2008 & -2.2234 & -2.1327 \\
\hline Panel B. Co-integration Tests among Explanatory Variables \\
Zrho \\
Zt & -13.8808 \\
ADFt & -2.6442 \\
\hline
\end{tabular}

In Panel A q: real \$/YTL; $y_{s, U S}-y_{s, T R}$ : short-term real interest difference; $y_{1 U S}-y_{1 T U R}$ : long-term real interest difference. Accept the null of a unit root if ${ }^{\mathrm{s}} \mathrm{ABF}>$ Critical Value or if ADF2 > Critical Value or if ADF3 < Critical Value or if Phillips-Perron Zrho > Critical Value, or if Phillips-Perron Zt $>$ Critical Value. The critical values for ADF and Phillips-Perron Zt are -3.485, -2.885, -2.575; for ADF2 and Phillips-Perron Zrho -20.05, -13.85, -11.1; and for ADF3 6.61, 4.66, 3.835 at 1\%, 5\%, and 10\%. In Panel B if Zrho $=$ Phillips Z Statistic $<$ Critical Value, there is evidence against no cointegration. Critical values are $-28.3,-20.5,-17.0$ at $1 \%, 5 \%$, and $10 \%$. If $\mathrm{Zt}=$ Phillips Z Statistic $<$ Critical Value or if ADFt $=$ Augmented Dickey-Fuller t Statistic $<$ Critical Value, there is evidence against no cointegration. Critical values for $\mathrm{Zt}$ and $\mathrm{ADFt}$ are $-3.39,-2.76,-2.45$ at $1 \%, 5 \%$, and $10 \%$.

\section{Cointegrating Regressions}

The last result of the previous section allows proceeding with Phillips and Hansen's fully modified OLS cointegrating regression (Phillips and Hansen, 1990). Real \$/YTL is regressed on both shortand long-term real interest rate differentials along with a constant term and a deterministic trend term. The results are reported in Panel A of Table 4. Point estimates have signs consistent with the theoretical conjectures. The point estimate for the real long-term interest rate difference is -0.0792 and is significant at $1 \%$. A higher long-term real interest rate in the US relative to Turkey causes a real and immediate appreciation of the dollar. In long run equilibrium, the dollar depreciates as suggested by the EH. Therefore, the UIP holds for long horizon rates. These results are consistent with those reported by Alexius (1993), Meredith and Chinn (1998), and Chinn and Meredith (2002), who also find that UIP holds in long-term analyses.

The slope coefficient for the short-term real interest rate differential is positive and significant. The point estimate of 0.8 indicates that the YTL and US short-term bonds are complements. This is consistent with Case 1 of Figure 1. Dulger and Cin (2002) examine cointegrating relationships between the nominal exchange rate and monetary variables for Turkey in a different context.

They reject the UIP for short-horizon interbank loan rates. The findings here are consistent with theirs in the short-term.

Gonzalo (1994) has shown that Johansen's maximum likelihood error correction model (Johansen, 1988) has better properties than the OLS, nonlinear least squares, principle component, and canonical 
correlation estimators. To make sure that the results are not specific to the choice of the estimation technique, the empirical analysis is replicated with Johansen's model. The results are reported in Panel B of Table 4.

Table 4

Cointegrating Regressions

\begin{tabular}{cc}
\hline Panel A. Phillips-Hansen's Fully Modified OLS Cointegrations & \\
\hline$\hat{\rho}_{1}$ & 0.8011 \\
& $(1320)$ \\
$\hat{\rho}_{2}$ & -0.0792 \\
& $(58)$ \\
$\hat{\rho}_{3}$ & 1.5440 \\
& $(10)$ \\
\hline Panel B. Johansen's Full Information Maximum Likelihood Estimates \\
\hline$\hat{\rho}_{1}$ & 1.59 \\
$\hat{\rho}_{2}$ & -3.46 \\
TraceStats & 48.25 \\
Eigenvalue Stats & 35.05 \\
\hline
\end{tabular}

Panel A: The regression has the form $q_{t}=\rho_{0}+\rho_{1}\left(y_{s, \text { US }}-y_{s, T U R}\right)+\rho_{2}\left(y_{1 \text { US }}-y_{1 T U R}\right)+\rho_{3} t+\varepsilon$, where $q_{t}$ is the real \$/YTL, $\left(\mathrm{y}_{\mathrm{s}, \text { US }}-\mathrm{y}_{\mathrm{s}, \mathrm{TUR}}\right)$ and $\left(\mathrm{y}_{1, \mathrm{US}}-\mathrm{y}_{1, \mathrm{TUR}}\right)$ are real short- and long-term interest rate differentials. $\chi^{2^{2}}$ statistics are in parentheses. Critical values are, $6.63,3.84,2.71$ at $1 \%, 5 \%$, and $10 \%$. Panel B presents normalized eigenvector values for short- and long-term interest rate differentials. Critical values for Trace and Eigenvalue statistics are 35.46 and 25.87 at $1 \%$.

The Johansen maximum likelihood method provides two different likelihood ratio tests to answer whether there is cointegration or not. These are the trace test and the maximum eigenvalue test. The vector error correction model representation uses a long run impact matrix, $\Pi$, which is the product of two matrices: one used to determine the deterministic part of the variables, and the other used for the cointegrating relationships. The trace likelihood ratio test statistic is obtained from $\Pi$

as $-T \sum_{i=r+1}^{p} \log \left(1-\lambda_{i}\right)$, where $r$ is the number of cointegrating vectors, $p$ is the rank of $\Pi, T$ is the sample size, and $\lambda_{\mathrm{i}}$ are the eigenvalues, ordered from smallest to largest, which arise in the solution of the reduced rank regression problem. The maximum eigenvalue likelihood ratio test statistic is defined as $-T \log \left(1-\lambda_{r+1}\right)$. If the trace statistic is greater than its critical value, then the null of no cointegration is rejected. Similarly, if the maximum eigenvalue statistic is greater than its critical value, then the null of no cointegration is rejected. The asymptotic distributions of the test statistics are nonstandard and their asymptotic critical values along with further details of the procedure are provided in MacKinnon et al. (1999), where the response surface approach has been adopted and Monte Carlo simulations have been conducted. Neither trace nor eigenvalue test statistics reject the null of no cointegration. The normalized eigenvector coefficients are consistent with previous regressions. Short rate difference has a positive (larger than 1) and long rate difference has a negative (less than -1) coefficient in explaining the YTL. 


\section{Robustness Tests}

Currency Depreciation vs. Interest Rate Differentials. In standard studies of currency - interest rate relationships, exchange rate depreciation is used as the dependent variable, as in Equation (4). In this section, the same procedure is followed to determine whether the conclusions of the previous sections are robust to this new set of regressions. The log difference of the $\$ / Y T L$ is regressed on the real short-term and long-term US-Turkish interest rate differentials. The \$/YTL change will have at most a fractal root after this difference. But the existence of unit roots in the explanatory variables makes the cointegration procedure also appropriate for the tests. First, OLS regressions are reported in Panel A of Table 5. As anticipated, the short-term rate differential has a negative slope coefficient which is significantly less than one. This is consistent with the FPP. On the other hand, the long-term rate differential has a positive and significant slope coefficient consistent with the EH and the UIP. Exact conclusions are obtained from Panel B of Table 5 where cointegrating regressions are used. FPP is seen short-term, however, the anomaly disappears long-term and the EH prevails.

Table 5

Change in Real \$/YTL vs. Real Short- and Long-Rate Differentials

Panel A. OLS Regressions

\begin{tabular}{|c|c|}
\hline \multirow[t]{2}{*}{$\hat{\rho}_{1}$} & -0.57 \\
\hline & $(-2.88)$ \\
\hline \multirow{2}{*}{$\hat{\rho}_{2}$} & 1.10 \\
\hline & $(2.29)$ \\
\hline \multirow{2}{*}{$\hat{\rho}_{3}$} & -0.02 \\
\hline & $(-0.08)$ \\
\hline \multicolumn{2}{|c|}{ Panel B. Phillips-Hansen's Fully Modified OLS Cointegrations } \\
\hline \multirow[t]{2}{*}{$\hat{\rho}_{1}$} & -1.53 \\
\hline & $(41)$ \\
\hline \multirow[t]{2}{*}{$\hat{\rho}_{2}$} & 1.22 \\
\hline & $(120)$ \\
\hline \multirow{2}{*}{$\hat{\rho}_{3}$} & 8.43 \\
\hline & $(25)$ \\
\hline
\end{tabular}

Regressions have the form $q_{t+1}-q_{t}=\rho_{0}+\rho_{1}\left(y_{\text {s.US }}-y_{\text {s,TUR }}\right)+\rho_{2}\left(y_{1, \text { US }}-y_{1, T U R}\right)+\rho_{3} t+\varepsilon_{t}$. In Panel A t-statistics for the short rate coefficient is for $\mathrm{H}_{0}: \rho_{1}=1$ to test the FPP. The others are for $\mathrm{H}_{0}: \rho=0$ and are reported in parentheses. In Panel $\mathrm{B}$ $\chi^{2}$ statistics are given in parentheses (with critical values of $6.63,3.84,2.71$ at $1 \%, 5 \%, 10 \%$ ).

\section{CONCLUSION}

This paper examines the relationship between the currency dynamics and interest rates of an emerging economy, Turkey, and a developed economy, the US. 1996-2006 corresponds to different patterns of controlled depreciation, sharp devaluation, and stable exchange rate periods. The new Turkish lira dynamics depend on both short-term and long-term US-Turkish interest rate differentials. As the 
Turkish central bank changes short-term rates to affect the \$/YTL movements, the reaction of longterm rates to these changes should also be taken into account because of the indirect influence of the long-term rate differential on the YTL. The term structure as a whole will determine the net impact of monetary policies on the $\$ / Y T L$.

Cointegrating regressions are performed on the contemporaneous \$/YTL with real short-term and real long-term interest differentials as explanatory variables. Regressions generate negative and significant coefficients for long-term rate differentials. This is consistent with uncovered interest parity, and the expectations hypothesis seems to be valid for long horizons. On the other hand, positive coefficients for real short-term interest rate differentials are consistent with the forward premium puzzle, which is the failure of uncovered interest parity for short-horizons. The results are robust to a different set of regressions where the dependent variable is the future \$/YTL change. The conclusions are consistent with the theoretical discussion in the paper. The US short-term bonds and the Turkish currency have very different risk characteristics. In a portfolio of securities, they serve as complements of each other. On the other hand, the long-term US bond is a suitable substitute for both the short-term US bond and the YTL. This particular risk order is one explanation of the empirical results.

The US was chosen as the developed country in the study. Even though the largest trading partner for Turkey is the European Union, Sayek and Selover (2002) find that the business cycles do not coincide, European and Turkish GDPs do not co-integrate, GDP growth rates are not correlated, and the income transmission effects due to trade may not be very large. Moreover, the composition of Turkish exports is in relatively income-inelastic goods, further weakening the transmission effects. Finally, much of the divergence of business cycles between Turkey and Europe may be due to many domestic and regional shocks specific to Turkey and unfelt in Europe. These were some reasons as to why the US was chosen as the foreign country in the study. Furthermore, the conversion of most European currencies into the Euro makes it difficult to find exchange rate and interest rate data which are not subject to government regulations and/or restrictions, and which can be used for an extended sample period. The requirement by the European Monetary Union from its member states to keep their currencies within a tight band relative to each other before the introduction of the Euro is one example of such restrictions. The analysis in the article can be applied to the Euro as more data become available.

\section{NOTES}

1. An exception is a study that examines both developed and emerging countries by Bansal and Dahlquist (2000). However, the study focuses on empirical panel analysis rather than theoretically explaining the dual country interest.

2. The statistical distribution of the interest rate data conducted by Gencay and Selçuk (2006) indicates abnormally high interest rates during the period. Telatar et al. (2003) examine the relationship between the term structure and inflation during the period and conclude that stability is only possible by reducing inflation through circumscribing substantial government budget deficits and the political instability underlying them.

3. These studies imply that the government should take further action to reduce the debt-ratio and real interest rates, and to accelerate structural reforms to attract foreign direct investment. Otherwise, the floating exchange rate period may just be another episode of appreciation-depreciation and/or boom-bust cycle in the Turkish economy. 
4. In a separate stream of research, rigorous stochastic models of the term structure of interest rates denominated in different currencies have been developed by Heath et al. (1992) and others to explain sudden and non-market driven changes in the exchange rate (e.g., during the Spring of 2001). The study here focuses on providing an explanation of the FPP. The comprehensive term structure model is left for future research.

5. As the demand for the US short bond increases, the demand for the US long bond decreases, which implies that the demand for YTL increases. US short bonds and the YTL are complements since their demand functions move in the same direction.

6. The strong substitutability between the US short-term and long-term bonds means that the demand for long-term bonds decreases. This decrease has the indirect effect of increasing the demand for YTL since long-term and foreign bonds are also strong substitutes.

7. In the next period under rational equilibrium, the YTL will lose value and the US dollar will appreciate, which is the forward premium anomaly. In a regression trying to explain the future changes in currency rates, the slope coefficient should be negative for short-term rates consistent with this anomaly.

8. The representative agent/investor uses the risk-neutral measure, $N$, to calculate expectations in a risk-neutral world. In such a world, the representative agent is indifferent to risk and requires no additional compensation.

9. In the steady state equilibrium next period, the currency will depreciate as suggested by the FPP, producing a negative slope coefficient between the currency change and short-term interest rate differentials. On the other hand, the long-term interest rate differentials will have positive slope coefficients when regressed against the exchange rate change.

10. The order of the AR process is determined from Schwarz, Akaike, Final Prediction Error, Shibata, and Hannan-Quinn information criteria. In both Turkey and the US, the order suggested by most criteria is used.

11. Considering interest rate in addition to the currency in the calculation of the Turkish investment volatility would not change the risk ranking of the three assets.

\section{REFERENCES}

Ahn, D.H., Dittmar, R.F., and Gallant, A.R. (2002). "Quadratic Gaussian Models: Theory and Evidence," Review of Financial Studies, 15: 243-288.

Akıncı, O., Culha, O.Y., Özlale, U. and Şahinbeyoğlu, G. (2006). “The Effectiveness of Foreign Exchange Interventions under a Floating Exchange Rate Regime for the Turkish Economy: A PostCrisis Period Analysis," Applied Economics, 38: 1371-1389.

Alexius, A. (1993). "UIP for Short Investments in Long-Term Bonds," Sveriges Riksbank Working Paper Series, No. 115. 
Ang, A. and Piazzesi, M. (2002). “A No-Arbitrage Vector Autoregression of Term Structure Dynamics with Macroeconomic and Patent Variables," Journal of Monetary Economics, 50: 745-787.

Backus, D., Foresi, S. and Telmer, C. (2001). "Affine Term Structure Models and the Forward Premium Anomaly," Journal of Finance, 56: 279-304.

Bali, T.G. (2000). "Modeling the Conditional Mean and Variance of the Short Rate Using Diffusion, GARCH, and Moving Average Models," Journal of Futures Markets, 20: 717-757.

Bansal, R. and Dahlquist, M. (2000). “The Forward Premium Puzzle: Different Tales from Developed and Emerging Economies," Journal of International Economics, 51: 115-144.

Barkoulas, J., Baum, C.F., and Chakraborty, A. (2003). "Forward Premiums and Market Efficiency: Panel Unit-Root Evidence from the Term Structure of Forward Premiums," Journal of Macroeconomics, 25: 109-123.

Baxter, M. (1994). "Real Exchange Rates and Real Interest Differentials: Have We Missed the Business-Cycle Relationship,” Journal of Monetary Economics, 33: 5-37.

Bekaert, G., Wei, M., and Xing, Y. (2002). "Uncovered Interest Rate Parity and the Term Structure," NBER Working Paper, No. 8759.

Bekaert, G. and Hodrick, R.J. (2001). "Expectations Hypotheses Tests," Journal of Finance, 56: 115138.

Berüment, H. (2007). "Measuring Monetary Policy for a Small Open Economy: Turkey," Journal of Macroeconomics, 29: 411-431.

Berüment, H. and Dinçer, N. (2004). "The Effects of Exchange Rate Risk on Economic Performance: the Turkish Experience," Applied Economics, 36: 2429-2442.

Brandt, M.W. and Santa-Clara, P. (2002). "Simulated Likelihood Estimation of Diffusions with an Application to Exchange Rate Dynamics in Incomplete Markets," Journal of Economics, 63: 161 210 .

Chinn, M. and Meredith, G. (2002). "Testing Uncovered Interest Parity at Short and Long Horizons during the Post-Bretton Woods Era," University of California, Santa Cruz Working Paper.

Collin-Dufresne, P., Goldstein, R.S., and Jones, C.S. (2004). "Can Interest Rate Volatility Be Extracted from the Cross Section of Bond Prices? An Investigation of Un-Spanned Stochastic Volatility," NBER Working Paper, No. 10756.

Dai, Q. and Singleton, K.J. (2002). "Expectation Puzzles, Time-Varying Risk Premia, and Affine Models of the Term Structure," Journal of Financial Economics, 63: 415-441.

----- (2003). “Term Structure Dynamics in Theory and Reality," Review of Financial Studies, 16: 631-678. 
Dickey, D.A. and Fuller, W.A. (1981). "Likelihood Ratio Statistics for Autoregressive Time Series with a Unit Root," Econometrica, 49: 1057-1072.

Dornbusch, R. (1976). "Expectations and Exchange Rate Dynamics," Journal of Political Economy, 84: 1161-1176.

Driskill, R. and McCafferty, S. (1987). "Exchange-Rate Determination: An Equilibrium Approach with Imperfect Capital Substitutability," Journal of International Economics, 23: 241-261.

Duarte, J. (2004). "Evaluating an Alternative Risk Preference in Affine Term Structure Models," Review of Financial Studies, 17: 379-404.

Dülger, F. and Cin, M.F. (2002). “The Determination of Foreign Exchange Rate Dynamics in Turkey: Monetary Approach and Testing with Cointegration Analysis," METU Studies in Development, 29: 47-68.

Edison, H. and Pauls, B.D. (1993). "A Re-Assessment of the Relationship between Real Exchange Rates and Real Interest Rates: 1974-1990,” Journal of Monetary Economics, 31: 165-187.

Engel, C. and West, K.D. (2004). “Accounting for Exchange Rate Variability in Present-Value Models When the Discount Factor is Near One," NBER Working Paper, No. 10267.

Erlat, H. (2003). “The Nature of Persistence in Turkish Real Exchange Rates," Emerging Markets Finance and Trade, 39: 70-97.

Ertuğrul, A. and Selçuk, R. (2001). "A Brief Account of the Turkish Economy, 1980-2000," Russian and East European Finance and Trade, 37: 6-30.

Euromoney Publications, PLC. (2006). “Country Risk Rankings," Euromoney, No. 443: 168-177.

Fama, E. (1984). "Forward and Spot Exchange Rates," Journal of Monetary Economics, 14: 319338.

Flood, R.P. and Rose, A.K. (2001). "Uncovered Interest Parity in Crisis: The Interest Rate Defense in the 1990s," IMF Working Paper, No. 01/207.

Frankel, J. (1979). "On the Mark: A Theory of Floating Exchange Rates Based on Real Interest Differentials," American Economic Review, 69: 610-622.

Fuller, W.A. (1996). Introduction to Statistical Time Series. New York: Wiley.

Gencay, R. and Selçuk, F. (2006). "Overnight Borrowing, Interest Rates and Extreme Value Theory," European Economic Review, 50: 547-564.

Gonzalo, J. (1994). "Five Alternative Methods of Estimating Long-Run Equilibrium Relationships," Journal of Econometrics, 60: 203-233. 
Hansen, L.P. and Hodrick, R.J. (1980). "Forward Exchange Rates as Optimal Predictors of Future Spot Rates: An Econometric Analysis,” Journal of Political Economy, 88: 829-853.

Heath, D., Jarrow, R., and Morton, A. (1992). "Bond Pricing and the Term Structure of Interest Rates: A New Methodology for Contingent Claims Valuation," Econometrica, 60: 77-105.

Hsieh, D.A. (1993). "Using Non-Linear Methods to Search for Risk Premia in Currency Futures," Journal of International Economics, 35: 113-132.

İnci, A.C. and Lu, B. (2004). "Exchange Rates and Interest Rates: Can Term Structure Models Explain Currency Movements," Journal of Economic Dynamics \& Control, 28: 1595-1624.

Institutional Investor, Inc. (2006). “Country Credit Ratings,” Institutional Investor, 40(3): 99-104.

Iwata, S. and Wu, S. (2005). "What Macroeconomic Risks Are (Not) Shared by International Investors?” Journal of Money, Credit, and Banking, 37: 1121-1141.

Johansen, S. (1988). "Statistical Analysis of Co-Integration Vectors," Journal of Economic Dynamics and Control, 12: 231-254.

Kempa, B., Nelles, M., and Pierdzioch, C. (1999). "The Term Structure of Interest Rates in a StickyPrice Target Zone Model," Journal of International Money and Finance, 18: 817-834.

MacKinnon, J.G., Haug, A., and Michelis, L. (1999). “Numerical Distribution Functions of Likelihood Ratio Tests for Cointegration,” Journal of Applied Econometrics, 14: 563-577.

Meredith, G. and Chinn, M.D. (1998). “Long-Horizon Uncovered Interest Rate Parity,” NBER Working Paper Series, No. 6797.

Meese, R. and Rogoff, K. (1988). "Was it Real? The Exchange Rate-Interest Differential Relation over the Modern Floating-Late Period," Journal of Finance, 43: 933-948.

Perron, P. (1988). “Trends and Random Walks in Macroeconomic Time Series," Journal of Economic Dynamics and Control, 12: 297-332.

Phillips, P.C.B. and Hansen, B.E. (1990). "Statistical Inference in Instrumental Variables Regression with I(1) Processes,” Review of Economic Studies, 57: 99-125.

Said S.E. and Dickey, D.A. (1984). "Testing for Unit Roots in Autoregressive-Moving Average Models of Unknown Order," Biometrika, 71: 599-607.

Sarno, L. and Valente, G. (2002). "Empirical Exchange Rate Models and Currency Risk: Some Evidence from Density Forecasts," Journal of International Money and Finance, 24: 363-386.

Sayek, S. and Selover, D.D. (2002). "International Interdependence and Business Cycle Transmission between Turkey and the European Union,” Southern Economic Journal, 69: 206-239. 
Selçuk, F. (2005). “The Policy Challenge with Floating Exchange Rates: Turkey’s Recent Experience," Open Economies Review, 16: 295-313.

Tastan, H. (2005). "Do Real Exchange Rates Contain a Unit Root? Evidence from Turkish Data," Applied Economics, 37: 2037-2054.

Telatar, E., Telatar, F. and Ratti, R.A. (2003). "On the Predictive Power of the Term Structure of Interest Rates for Future Inflation Changes in the Presence of Political Instability: The Turkish Economy," Journal of Policy Modeling, 25: 931-947.

Us, V. (2004). "Inflation Dynamics and Monetary Policy Strategy: Some Prospects for the Turkish Economy," Journal of Policy Modeling, 26: 1004-1014.

Wu, S. (2007). "Interest Rate Risk and the Forward Premium Anomaly in Foreign Exchange Markets," Journal of Money, Credit, and Banking, 39: 23-442.

Zhou, A. (2002). "Modeling the Volatility of the Heath-Jarrow-Morton Model: A Multi-Factor GARCH Analysis," Journal of Empirical Finance, 9: 35-56. 